DOI https://doi.org/10.30525/978-9934-26-075-9-36

\title{
MODERN SOCIO-PSYCHOLOGICAL PORTRAIT OF A MEDICAL INTERN
}

\author{
Yekhalov V. V. \\ Candidate of Medical Sciences, \\ Associate Professor at the Department of Anesthesiology, Intensive Therapy \\ and Emergency Medicine of Postgraduate Education Faculty \\ Dnipro State Medical University \\ Kravets O. V. \\ Doctor of Medical Sciences, \\ Head of Department of the Anesthesiology, Intensive Therapy \\ and Emergency Medicine of Postgraduate Education Faculty \\ Dnipro State Medical University \\ Krishtafor D. A. \\ Candidate of Medical Sciences, \\ Assistant Professor at the Department of Anesthesiology, \\ Intensive Therapy and Emergency \\ Medicine of Postgraduate Education Faculty \\ Dnipro State Medical University \\ Dnipro, Ukraine
}

Over the past decade, we have faced progressive changes in public conscioussness: moral and ethical norms, culture of behavior and communication, the ability to absorb information and the deviation of thinking of modern youth at the stage of postgraduate education. In our teaching, today we encounter a generation born in 1983-2002, which modern sociologists have termed Generation Y or "millennials" [1]. Our department staff developed an anonymous survey to highlight the hidden socio-psychological characteristics of surveyed individuals. After analyzing a number of scientific publications and the results of the survey, we were able to partially describe the sociopsychological portrait of a modern young colleague, some of his psychological and social personality traits.

Based on a long-term targeted observation in groups trained in the "Emergency medicine" course at the beginning of the last decade, we identified certain intern psychotypes [2], and now considered the dynamics of the individual characteristics' distribution amongst them. Thus, the "ideal 
variant", which accounted for $72 \%$ of all respondents ten years ago, has now barely reached $64.5 \%$; share of the "carefree" at the same time has almost doubled (to 7.5\%); "unreasonably self-confident" - tripled (from 4\% to $12.5 \%)$; "slow-moving" share increased from $4 \%$ to $9.5 \%$.

The millennials stubbornly don't want to say goodbye to childhood and take responsibility, either for themselves or for others. In the last 3-4 years there have been cases of interns' mothers reaching the professors with a request to ease the training and production requirements for their children. Generation $\mathrm{Y}$ is often overly pampered by parents who themselves grew up in the years of total scarcity, which made them consciously dependent [3, 4].

Millenials have a strong sense of individuality. It's very important for them to express their point of view and to have the opportunity to show their talents and maximize their potential [5,]. Their high communicability is complicated by their individualism and a desire for isolation. They have a wide range of acquaintances without obligations and fast-changing interests and hobbies. [6]. They manage to create their ideal virtual world, with their own laws, which leads to the great naivety and ignorance of the realities of the world $[3,5]$. Lack of communication experience, inability of modern youth to agree and yield is a characteristic feature of today. [7].

Millenials are very ambitious, devoid of a stereotyped approach to knowledge. They don't seek to build a career in the traditional sense, they don't care about career growth and constant pursuit of solid positions and higher salaries [3]. However, $69.2 \%$ of the surveyed interns aspire to hold the chair of a senior manager in the future, but according to individual characteristics, only $31.2 \%$ of them have the abilities for this. Nevertheless, 93.5\% of them showed the highest self-esteem.

Modern youth is characterized by fragmentary (clip) thinking as an increasingly progressive process. They hurry to do short-term work, but they don't know how to prioritize the long-term tasks, so many tasks remain unfinished [8]. Thus, $43.2 \%$ of respondents consider it appropriate not to perform certain tasks if it doesn't bear negative consequences for them. In selfpreparation for classes, more complex and extensive tasks are postponed, which was confirmed by $56.2 \%$ of respondents. According to the survey, $69,5 \%$ of modern respondents consider themselves procrastinators (against $78.5 \%$ in 2011).

Representatives of Generation $\mathrm{Y}$ are characterized by a certain "energy saving" in the process of studying topics which are not very interesting for them personally. Their answers indicate that $72.2 \%$ would not have neglected the use of fraudulent methods during the survey and testing, if not for the precautionary actions of the professor. Only $7 \%$ of young colleagues consider 
themselves able to reproduce the received information perfectly (previous result - 16.5\%), 35.5\% - well (against 47.5\%), 40.5\% moderately (against $32.5 \%$ ), and $17 \%$ - unsatisfactory (against 3.5\% 10 years ago).

Millenials interact organically with the digital world, respond to its innovations and implement them in their lives [6]. They prefer to have a flexible and convenient schedule of classes, which would allow secondary employment. Accordingly, they would prefer distance learning to face-to-face forms of training, and webinars to classical lectures [9. 72.4\% of general Generation $\mathrm{Y}$ population prefer distance learning, but among interns it amounts only to $9.2 \%$.

Young colleagues well understand productive dosed humor, appropriate references to quotes from scientists of the past, but rarely - the examples from the classic literature. According to the survey, the number of "book lovers" among interns has decreased by $21.5 \%$ over the past decade. But the doctor's professional competence ultimately depends on his ability to speak, the level of his language culture [10].

For millennials, the main thing is success (92\%). They are focused on the rapid professional development of their skills, but are not tied to the profession or place of work and can seriously change their lives by choosing another, more interesting direction for self-development, not perceiving frequent work changes as stress. They prefer to develop horizontally rather than vertically, gaining more experience in several areas. Rigid staff hierarchy, fixed hours, and monotony in work are disadvantageous for them [5, 6]. 96.4\% of current interns want to receive high salaries in the future, but only $54.5 \%$ of them agree to work hard and productively.

Millennials are very easily offended, even the requirements of the discipline often cause stress and irritation for them [11]. The mood after such excesses quickly recovers only in $18.1 \%$ of respondents, others $(49.1 \%$ of respondents) tend to "scroll in the head" past experiences again and again. $57.9 \%$ of interns surveyed reported that they were under stress all or most of the time of the course.

Although millennials often demonstrate a high level of knowledge and skills at a young age, however, they lack maturity when it comes to the concept of behavior in the workplace [8]. Thus, nowadays $71.5 \%$ of respondents believe that it's appropriate to leave the audience at any time (compared to $7.5 \%$ in 2010), $46.5 \%$ believe in their right to use mobile communications in the classroom (previously - 12\%).

The social situation of the 1990s formed in children and adolescents, who had grown up at that time, a reluctance to make long-term plans [6]. Among the respondents, only $34.6 \%$ have long-term plans for further life and work. 
Lack of social mobility (49.2\% of respondents) and income inequality (44.5\% of respondents) were mentioned as the main problems of our time. $79.4 \%$ of respondents show respect for the elderly, expecting nothing from them. Only $61.1 \%$ respect the professor only because of his position, and $97.2 \%$ - for his professional, teaching and personal qualities.

Generation $\mathrm{Y}$ has the desire and willingness to change life in their country. They are less ideological than previous generations, but not devoid of patriotism. In addition, they are more likely than other generations $(65 \%)$ to believe that the country is developing in the right direction [5]. According to a Deloitte Global Millennial Survey 2020 conducted in many countries around the world, almost three-quarters of respondents in Ukraine included that the pandemic has made them more sympathetic to the needs of others and that they intend to take action to make a positive impact on their communities [12]. $84.2 \%$ of interns recognize the leading role of medical deontology in medical practice and adhere to its principles. Only $6.9 \%$ of respondents want to work in foreign clinics in the future, and $84.3 \%$ of respondents are ready to make every effort to improve health care in Ukraine.

Current generation is no worse than the previous ones, they are simply not like us, and they need to be taught differently, maximally motivating the preservation of existing intellectual and moral values. They need an individual personal approach, which will allow to transform the downsides of "clip thinking", features of behavior and attitude to the educational process, and modern passion for gadgets and manner of communication, into positive qualities.

\section{References:}

1. Mannheim K. Diagnosis of Our Time: Wartime Essays of a Sociologist. Psychology Press, NY, USA, 1997. 180 p.

2. Клигуненко Е.Н., Ехалов В.В., Слива В.И., Станин Д.М., Лященко О.В. Перспективы оптимизации подготовки врачей-интернов по модулю «Неотложные состояния». Медицина неотложных состояний. 2012. № 5(44). С. 71-74.

3. Литвинова Н.П. Поколение «Ү»: а где же у него кнопка? Вестник Алтайской академии экономики и права. 2018. № 4. С. 77-82.

4. Yekhalov V.V., Kravets O.V., Krishtafor D.A. Psychological Features of the Modern Intern. The world of science and innovation. Abstracts of the 6th International scientific and practical conference. London, UK, 2021. P. 304-311. 
5. Хомякова Е.И. "Поколение Y" в контексте социального взаимодействия в современном обществе. Известия Томского политехнического университета. 2011. т. 319. № 6. С. 153-156.

6. Белоусова М.В., Карпов А.М. Клиентоориентированные техники эффективного взаимодействия в психологической деятельности (психологический практикум). Казань, РФ, 2019. 48 с.

7. Ильинская С.Г. Человек манипулируемый (политическая нестабильность как ожидаемое следствие современных образовательных технологий). Философская мыслль. 2019. № 11. С. 1-10. DOI: $10.25136 / 2409-8728.2019 .11 .31441$

8. Тулган Б. Не всем достанется приз. Как управлять поколением «игрек». - М.: ООО Манн, Иванов, Фербер, 2017. 256 с.

9. Осетрова О.О., Борисова Ю. В., Пірог Л. А. Викладач очима студентів: реконструкція образу за допомогою методу незакінчених речень. Науковий часопис Національного педагогічного університету імені М. П. Драгоманова. Серія 5 : Педагогічні науки : реалї та перспективи : зб. наук. пращь. 2018. № 63. С. 148-153.

10. Ехалов В.В., Самойленко А.В., Романюта И.А., Баранник С.И., Мизякина Е.В. Проблема культуры речи в современнном высшем медицинском образовании. Украӥнський журнал медицини, біологіï та спорту. 2020. Т.5, №3(25). С.392-397. https://doi.org/ 10.26693/jmbs05.03.392

11. Водопьянова Е.В. Миллениалы: российская и европейская версии. Научно-аналитический вестник ИЕ РАН. 2020. №1. С. 129-133. http://dx.doi.org/10.15211/vestnikieran12020129133

12. DTTL Team. The Deloitte Global Millennial Survey 2020. Delotte Global, 2020.31 p. 